\title{
Correlative Supply and Demand Functions in Lupinus havardii: A Forgotten Side of Cut Flower Physiology?
}

\author{
G.A. Picchioni ${ }^{1}$ \\ Department of Plant and Environmental Sciences, New Mexico State University, Las Cruces, \\ NM 88003
}

\author{
Wayne A. Mackay \\ Texas A\&M Research and Extension Center, 17630 Coit Road, Dallas, TX 75252 \\ Mario Valenzuela-Vázquez \\ Universidad Autónoma de Ciudad Juárez, Anillo Envolvente del Pronaf y Estocolmo s/n, Col. Zona \\ Pronaf. C.P. 32300. A.P. 1595-D. Cd. Juárez, Chihuahua, México
}

\begin{abstract}
ADDITIONAL INDEX wORDS. mineral transport, phloem, dry matter, water balance, remobilization, sink-to-source transition, abscission, developmental plasticity

Abstract. Correlative control of long-distance transport processes consists of an attraction or mobilizing power of a sink organ coupled to internal degradative reactions in a target source organ and the reallocation of its resources. This phenomenon is widely recognized in the agronomic whole plant literature but poorly recognized in the floriculture literature. We calculated supply and demand balances for water, total dry matter (TDM), and minerals during a 6-day postharvest evaluation of the spatially diverse, detached, indeterminate inflorescence of Lupinus havardii Wats. 'Texas Sapphire' held in deionized water. The apex approximately doubled its original (harvest day) amounts of total $\mathrm{N}, \mathrm{P}, \mathrm{K}, \mathrm{Mg}$, and $\mathrm{S}$ and increased its $\mathrm{TDM}$ and water content by $55 \%$ and $85 \%$, respectively, all at the expense of lower-most mature flowers. Net export from the lower mature flower fraction and, when applicable, upper mature flowers, accounted for the following apical gains: $46 \%$ of TDM, $102 \%$ of water, $100 \%$ of $\mathrm{N}, 94 \%$ of $\mathrm{P}, 99 \%$ of $\mathrm{K}$, and $54 \%$ of $\mathrm{Mg}$ and S. Directed reallocation of resources from the senescing lower mature flowers (the main "target") to the apical sink (the "mobilizing center") bore a marked resemblance to the coupling of remote sink demand with vegetative decline reported in monocarpic plants (i.e., vegetative-to-reproductive exchanges), but with two distinguishing characteristics: 1) the TDM and mineral exchanges were strongly restricted to flowering units, and 2) the contributions of water, $N$, $P$, and $K$ exports to apical sink demand were at or near $100 \%$. This article is the first that we are aware to provide an internal supply and demand balance sheet reflecting, quantitatively, the postharvest reallocation of internal resources from mature reproductive tissues to generative reproductive tissues of a cut inflorescence.
\end{abstract}

Lupinus havardii (big bend bluebonnet) is a new introduction to the U.S. specialty cut flower trade and has excellent niche market potential (Davis et al., 1994; Mackay and Davis, 1998). However, this potential is limited by rapid perishability associated with high sensitivity to endogenous and exogenous ethylene (Davis et al., 1995; Sankhla et al., 2001; Vasquez, 1998). Display life of $L$. havardii is as short as $7 \mathrm{~d}$ in normal atmosphere with water as the vase solution and no preconditioning treatment (Davis et al., 1995).

The cut $L$. havardii raceme is leafless and indeterminate (Dracup and Kirby, 1996). Once cut and placed in a vase of water, the raceme continues to elongate and support newly opened flowers arising from lateral primordia in the apical meristem. Apical expansion of the freshly cut raceme results in an early 1 - to $2-\mathrm{d}$ increase in total inflorescence fresh weight.

Received for publication 7 June 2006. Accepted for publication 5 Oct. 2006. This study was supported by the New Mexico Agricultural Experiment Station, USDA/CSREES Rio Grande Basin Initiative Grants (awards 2005-3446115661 and 2005-45049-03209), USDA/CSREES Hispanic Serving Institutions Grants (award 2002-38422-12144), and the Fred C. Gloeckner Foundation. We thank Dr. Rod Bieleski for clarifications and insights on his floriculture research and Drs. John Mexal and Steven Newman for helpful comments.

${ }^{1}$ Corresponding author. E-mail: gpicchio@nmsu.edu
Within a few days, the total flower number per raceme increases by as much as $50 \%$ above the harvest day flower number, but eventually, the whole raceme loses $15 \%$ to $25 \%$ of its initial fresh weight. Desiccation is synchronized with expansion of the apex and confined exclusively to mature flowers present at time of harvest (Picchioni et al., 2002).

"Correlative control" is recognized as a significant developmentally regulated process in whole plant (monocarpic) senescence. In the correlative control process, a senescing vegetative source and a generative reproductive sink influence each other and thereby coordinate development of the other organ (Noodén, 1988; Thomas and Stoddart, 1980). Visual observations suggest that a detached indeterminate inflorescence such as that of $L$. havardii has an autonomous habit of correlative control between distant reproductive structures. That is, the desiccating flowers may function as resource "salvage" organs in support of metabolic demands of expanding buds and flowers.

Plants preferentially direct internal resources to maximize reproductive gain; thus, reproductive structures have a logical role in regulating the metabolism of parts that supply them (Noodén, 1988). Although bud opening on cut indeterminate inflorescences is a resource-limited and horticulturally 
important process (Schroeder and Stimart, 2001; Serek et al., 1994), there are few quantitative data on long-distant transport processes in cut flowers, namely the export of endogenous minerals and assimilates from a reproductive source coupled to the import of endogenous resources by a reproductive sink. A frequently used example of cut flower source:sink relations is the determinate inflorescence of 'White Sim' carnation (Dianthus caryophyllus L.) (Nichols and Ho, 1975a, 1975b). These papers are referenced in major reviews on cut flower postharvest physiology (Borochov and Woodson, 1989; Halevy and Mayak, 1979), current literature on senescence in higher plants (Thomas et al., 2003), and several reports cited in the present investigation. Findings from the latter studies revealed an ethylene-dependent competition between gynoecium and mature petals for vase or petal-applied ${ }^{14} \mathrm{C}$-sucrose.

Senescing petals on the uncut daylily (Hemerocallis $\times$ hybrida Hort.) lost over $80 \%$ of their maximum amounts of endogenous amino- $\mathrm{N}$ and soluble sugars, and a significant quantity of ${ }^{14} \mathrm{C}$-sucrose that was applied to senescing petals traveled to immature flower buds (Bieleski, 1995). Presenescent $\mathrm{N}, \mathrm{P}$, and $\mathrm{K}$ content in petals of uncut petunia (Petunia $\times$ hybrida Hort. ex Vilm.) fell by $50 \%$, 75\%, and $40 \%$, respectively, by termination of petal development (Verlinden, 2003). In both studies, endogenous assimilate or mineral data were expressed as mass per petal or corolla, as is appropriate, although parallel quantitative measures of accumulation of internally derived (naturally occurring) solutes by a sink were not established. In cut gladiolus (Gladiolus $\times$ hybridus Hort.), Waithaka et al. (2001) observed net losses in dry matter per floret at basal inflorescence positions $5 \mathrm{~d}$ after cutting, coinciding with net dry matter gains per floret at the more apical positions. In that study, contributions by various dry matter source organs to the apical floret dry matter gains were not quantitatively established.

Lack of a quantitative database and the contemporary view of flower development as a "unidirectional" process (Thomas et al., 2003) question assumptions about how cut inflorescences support resource demands of their newly opening flowers. Although it appears logical to expect meristematic tissues of a cut inflorescence to depend entirely on outside sources for their assimilate and mineral needs, that expectation is not supported by quantitative data as it is in the whole plant literature (Hill, 1980; Pate, 1975). We hypothesized that postharvest growth of the L. havardii apical meristem is supported by redistribution of resources from mature regions of the inflorescence. Our objectives were to identify the source organs supporting apical sink demand for water, dry matter, and minerals, and to prepare quantitative balances of the resources between sink and source.

\section{Materials and Methods}

Greenhouse Cultivation AND RACEME harvest. Seeds of L. havardii 'Texas Sapphire' were scarified, sown in flats, and transplanted individually into $12-\mathrm{L}$ plastic pots $(25-\mathrm{cm}$ top diameter $\times 24-\mathrm{cm}$ height) containing Metromix 200 (The Scotts Co., Maryvsille, Ohio). A total of 136 potted plants were arranged in four adjacent, 34-pot plots and grown in a greenhouse for 5 months to obtain harvestable racemes. The daytime maximum air temperature ranged from 24 to $31{ }^{\circ} \mathrm{C}$, the minimum air temperature from 13 to $18{ }^{\circ} \mathrm{C}$, and the maximum midday photosynthetic photon flux at crop level from 550 to $1250 \mu \mathrm{mol} \cdot \mathrm{m}^{-2} \cdot \mathrm{s}^{-1}$. Pots were fertigated throughout the culture period with $\mathrm{N}$ at $100 \mathrm{mg} \cdot \mathrm{L}^{-1}, \mathrm{P}$ at $44 \mathrm{mg} \cdot \mathrm{L}^{-1}$, and $\mathrm{K}$ at $83 \mathrm{mg} \cdot \mathrm{L}^{-1}$ supplied by Peters $20 \mathrm{~N}-8.7 \mathrm{P}-16.6 \mathrm{~K}$ water-soluble fertilizer (The Scotts Co.). The fertilizer supplied no $\mathrm{Ca}, \mathrm{Mg}$, or $\mathrm{S}$, but the tap water source provided $\mathrm{Ca}$ at $50 \mathrm{mg} \cdot \mathrm{L}^{-1}, \mathrm{Mg}$ at $8 \mathrm{mg} \cdot \mathrm{L}^{-1}$, and $\mathrm{S}$ at $65 \mathrm{mg} \cdot \mathrm{L}^{-1}$ (as sulfate) with no additional $\mathrm{N}, \mathrm{P}$, or $\mathrm{K}$. Fertigation was supplied when an average of $\approx 50 \%$ of total medium water storage had been depleted with applied volumes sufficient to cause a $6 \%$ to $14 \%$ leaching fraction.

Racemes were harvested using previous guidelines for mature L. havardii inflorescences (Mackay and Davis, 1998). As the individual racemes were harvested (0900 and $1000 \mathrm{HR}$ ), the bases of the peduncles were placed in deionized water and then recut under water to a final length of $\approx 15 \mathrm{~cm}$. On the day of harvest, 16 racemes were collected from each of the four greenhouse plots, eight for the harvest day destructive analysis (hereafter referred to as the day 0 racemes) and the other eight for nondestructive analysis during 6-d simulated vase life conditions followed by their destructive analysis at the end of the 6-d evaluation (hereafter referred to as the day 6 racemes). A total of 64 racemes were harvested and, with their peduncle bases still in water, taken immediately to the laboratory for postharvest evaluations.

LABORATORY POSTHARVEST EVALUATIONS. Within $2 \mathrm{~h}$ of harvest, fresh weights of the day 0 and day 6 racemes were obtained. The day 0 racemes were fractionated into the following parts: peduncle, lower rachis, upper rachis, lower (older) half of mature flowers including pedicels, upper (younger) half of mature flowers including pedicels, and the unexpanded apex (left diagram in Fig. 1). Mature lower and upper flowers were fully expanded at harvest. The sampling pooled the eight racemes per experimental unit, which provided the minimum amount of dry matter for subsequent analysis.

On day 0 racemes, the unexpanded apex was cut at the rachis just above the pedicel subtending the most recently opened upper mature flower. The peduncle was blotted dry, fresh weights of all fractions were recorded, and the tissues were dried at $60{ }^{\circ} \mathrm{C}$ for $48 \mathrm{~h}$. After obtaining total dry matter (TDM) of the day 0 raceme fractions, the weight of water in each fraction was calculated, then the tissues were ground in liquid $\mathrm{N}_{2}$ using a mortar and pestle to pass a 60 -mesh $(0.25-\mathrm{mm})$ screen, and saved in a desiccator under vacuum at room temperature for mineral analyses.

Within $3 \mathrm{~h}$ of harvest, day 6 racemes were placed individually in tubes holding a constant daily supply of deionized water. Approximately $90 \%$ of the peduncle's length was submerged in the simulated vase (uptake) solution, and the tubes were sealed with parafilm to eliminate evaporation losses from the surface. Racks were used for support and to maintain spatial separation of the replications, each holding eight individual racemes. The midpoint of the mature flowers and base of the unexpanded apex were marked on the rachis with water-based ink to aid in later fractionation. The mature flowers were counted on both lower and upper halves of the rachis and denoted as harvest day (day 0) counts. The day 6 racemes were then allowed to stand in the laboratory for $6 \mathrm{~d}$ of postharvest evaluation at $24 \pm 1{ }^{\circ} \mathrm{C}, 30 \%$ to $50 \%$ relative humidity, photosynthetic photon flux of 20 to $25 \mu \mathrm{mol} \cdot \mathrm{m}^{-2} \cdot \mathrm{s}^{-1}$ under cool-white fluorescent lamps, and a 24-h photoperiod.

Daily transpiration of the day 6 racemes (grams of water per eight racemes) was defined as the loss in total rack weight over 


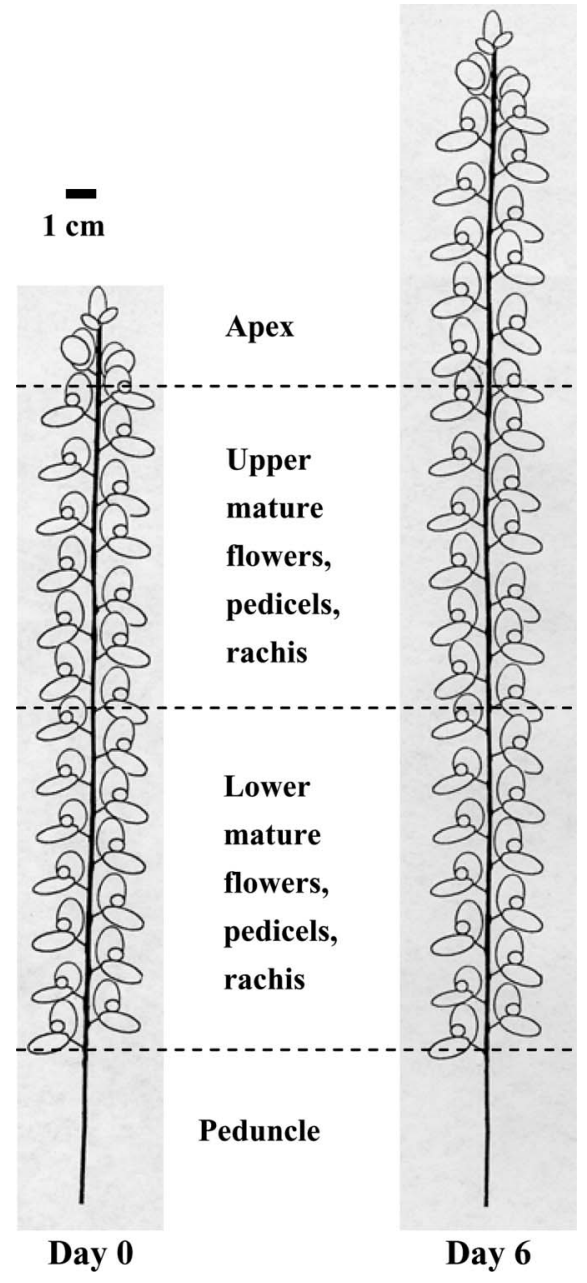

Fig. 1. Representation of the cut Lupinus havardii 'Texas Sapphire' raceme at harvest (day 0) and after postharvest evaluation (day 6). Dashed horizontal lines delineate the boundaries of inflorescence tissues analyzed in the experiment. Scale line is $\approx 1 \mathrm{~cm}$. Redrawn from Vasquez (1998).

24-h periods. This measurement discounted respiratory losses, but total raceme dry matter loss over $6 \mathrm{~d}$ represented only $\approx 1 \%$ of average daily transpiration. Daily water uptake (grams per eight racemes) was defined as the total rack weight after replenishing the tube volumes minus the total rack weight taken immediately before daily water addition. Abscised flowers were included in all rack weights and had an average water content (fresh weight basis) of $24 \%$ as compared with $\approx 90 \%$ for fresh mature flowers on the rachis. After $6 \mathrm{~d}$ in the laboratory, the number of newly opened flowers at the apex plus the numbers of lower and upper mature flowers still retained on the rachis were counted. At this time, the day 6 raceme appeared as shown in the right image of Figure 1, which for diagrammatic simplicity omits senescence and abscission of mature flowers. These racemes were then fractionated and processed as described for the day 0 racemes with all mature flower weights including the weights of any flowers that had abscised in the laboratory.

Mineral analyses. Mineral determinations were made on ground subsamples of the homogenized eight-raceme experimental unit. Subsamples of $150 \mathrm{mg}$ were subjected to acid block digestion for determining total Kjeldahl $\mathrm{N}$ concentration on an autoanalyzer (Technicon AAII; Technicon Instruments, Tarrytown, N.Y.) using the extraction procedures of Gavlak et al. (1994). Separate 150-mg ground subsamples were subjected to microwave digestion (Jones et al., 1991), to determine concentrations of $\mathrm{P}, \mathrm{K}, \mathrm{Ca}, \mathrm{Mg}$, and $\mathrm{S}$ using a plasma emission spectrometer (JY 70+; Instruments S.A., Edison, N.J.). Mineral analyses of mature flowers on day 6 racemes included any that had abscised in the laboratory. Mineral content (milligrams per fraction) was determined as the product of fraction dry weight (grams) by elemental concentration (milligrams per gram dry weight).

EXPERIMENTAL DESIGN AND STATISTICAL ANALYSES. The study was replicated four times with each greenhouse plot providing a replication of eight racemes. For the day 6 racemes, daily counts of retained and abscised mature flowers at both lower and upper positions are presented as the mean \pm SE per individual raceme. Data for all remaining response variables were processed by repeated measures analysis of variance and based on eight pooled racemes per replication using Statistix 8 (Analytical Software, Tallahassee, Fla.). Linear, quadratic, and cubic effects of postharvest days on raceme transpiration and solution uptake were incorporated into the analysis of variance. For weights of fresh matter, water, TDM, and minerals, postharvest day was a between-subject factor and inflorescence fraction was the within-subject factor. For the latter response variables, the least significant difference ${ }_{0.05}$ values for within and between postharvest days were computed following Steel and Torrie (1980) for repeated measures analysis of variance. Of the 66 total possible fraction $\times$ postharvest day paired comparisons for each response variable, there were three preplanned, between postharvest day comparisons of primary interest. These comparisons were between the 0 -day and 6-day averages within the apex, lower mature flowers, and upper mature flowers.

INTERORGAN SUPPLY AND DEMAND BALANCES. Supply and demand balances within the cut raceme were calculated on the basis of eight racemes and considered only the fractions that expressed significant change in water, TDM, and mineral content between 0 and $6 \mathrm{~d}$ postharvest life, based on the least significant difference ${ }_{0.05}$ between days. For the raceme water and TDM balances, these fractions were limited entirely to the apex and mature flower fractions. We compared the accrued deficits in water and TDM in mature flowers with net water and TDM gains by the apex. This comparison did not account for absolute water losses or gains; thus, it only disclosed a possible contribution of net water loss by the mature flowers to net water gain by the apex. Net export (redistribution) of water and TDM from the mature flowers was estimated by subtracting the total net losses per eight racemes from all fractions weighed together (i.e., water vapor and respiratory losses to the atmosphere) from the sum total of individual net fractional losses subjected to both loss to the atmosphere and redistribution. That is, redistribution represented "loss" from an inflorescence fraction but not to the atmosphere. The contributions of water and TDM redistribution from the mature flowers were then expressed as a percentage of net apical water and TDM gains. The apparent export of water and TDM from the mature flowers was also expressed as a percentage of their initial (day 0 ) water and TDM content.

The mineral balances were calculated as described previously for water and TDM with the exception of counting a relatively small $\mathrm{N}$ gain by the upper rachis fraction in the cut 
raceme $\mathrm{N}$ balance. Net losses of minerals from the mature flowers were defined as the difference in mineral content between day 0 (maximum content) and day 6 (minimum content) of postharvest evaluation. The contributions of mineral losses were then expressed as percentages of apical mineral gains. Mineral remobilization efficiencies were expressed as a percentage reduction in mineral content between day 0 and day 6.

\section{Results}

Flower ABSCISSION AND OPENING. An average of $6.4 \pm 0.6$ mature flowers per raceme out of an initial $26.9 \pm 1.2$ mature flowers per raceme had abscised during the $6 \mathrm{~d}$ postharvest evaluation (Fig. 2A). Most of the abscission (80\%) occurred at the lower positions $(5.1 \pm 0.4$ flowers per raceme $)$ and $20 \%$ at the upper, more recently expanded positions ( $1.3 \pm 0.3$ flowers per raceme). Abscission was gradual throughout evaluation but was concentrated between 2 and $5 \mathrm{~d}$ after harvest (Fig. 2B). On average, 8.4 lower mature flowers and 12.1 upper mature flowers per raceme remained on rachis on day 6 (Fig. 2A). At this time, the number of newly opened flowers at the apex (not shown in Fig. 2) averaged $11.1 \pm 0.3$ per raceme, and the upper region of the inflorescence resembled the right-side apical image of Figure 1.
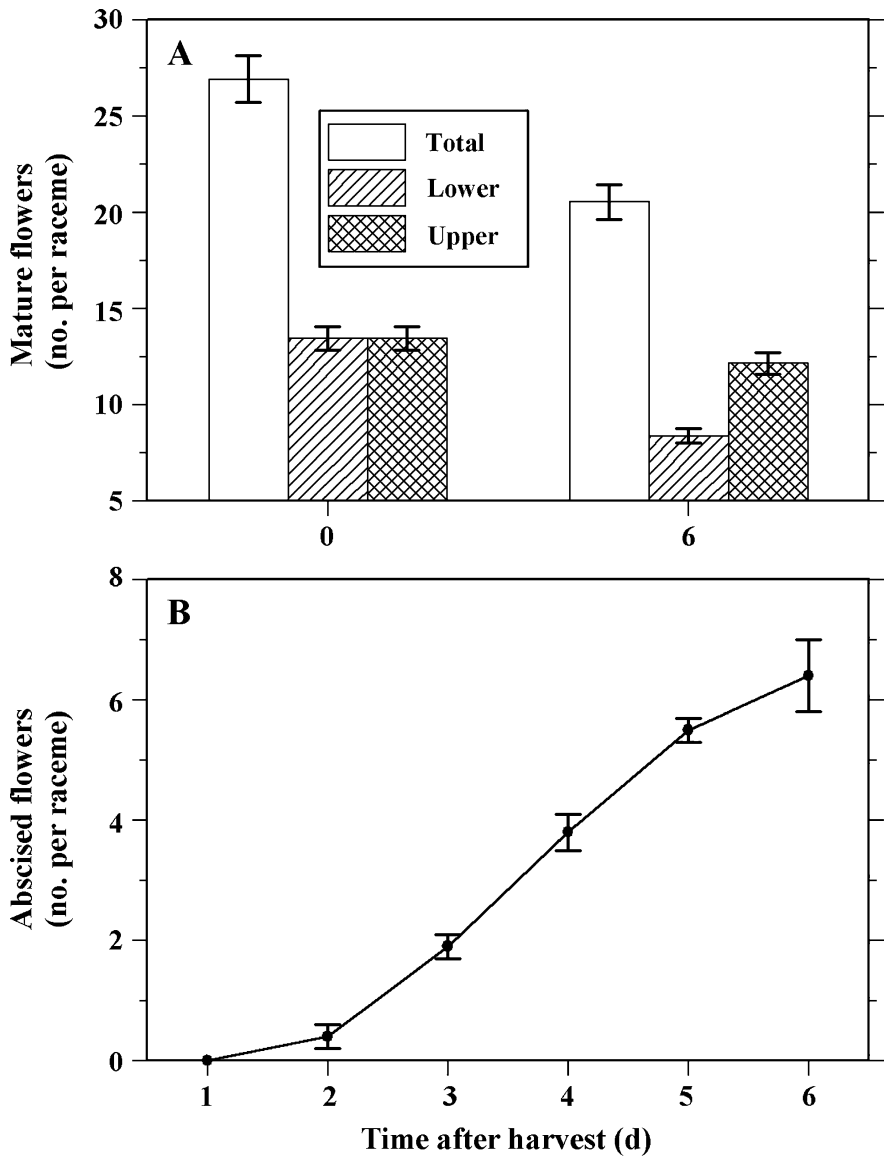

Fig. 2. Total, lower, and upper mature flower counts on Lupinus havardii 'Texas Sapphire' racemes at harvest (day 0) and after postharvest evaluation (day 6) (A) and cumulative mature flower abscission on each day (B). Values are the means \pm SE of four replications, each the average of eight individual racemes.
RACEME WATER BALANCE, FRESH WEIGHT, AND DRY WEIGHT. Postharvest solution uptake and transpiration per eight racemes declined linearly from $2 \mathrm{~d}$ to $6 \mathrm{~d}$ of vase life (Table 1 and Fig. 3). Higher-order trends resulted from the rise in solution uptake between days 1 and 2. On day 1, solution uptake lagged behind transpiration by $4.5 \mathrm{~g}$ per eight racemes and thereafter by an average of $1.5 \mathrm{~g}$ per eight racemes.

The response variables of fresh weight and weight of water shared similar trends among raceme fractions and across the two postharvest dates (Fig. 4A, B). Fresh weight and weight of water were affected by raceme fraction, postharvest days, and the postharvest days $\times$ fraction interaction (Table 1). For TDM, only the fraction main effect and the postharvest days $\times$ fraction interaction were significant (Table 1). The interaction resulted largely because of the inverse postharvest changes in fresh weight, weight of water, and TDM between the apex and mature flowers. There was no main effect of postharvest days on TDM per fraction, which averaged 0.73 and $0.68 \mathrm{~g}$ per eight racemes on days 0 and 6 , respectively (Fig. 4C).

The shortfall in solution uptake relative to transpiration resulted in a $13 \%$ net reduction in total fresh weight and a $14 \%$ net reduction in the weight of water per eight racemes below the day 0 average (Fig. 4A, B). There were marginal fresh weight and water weight increases in the submerged peduncle. Any other postharvest change in fresh weight, weight of water, and TDM occurred only in apex and mature flowers. Within $6 \mathrm{~d}$, the lower mature flower fraction lost $81 \%$ of its fresh weight and $88 \%$ of its water, whereas the upper mature flower fraction lost $33 \%$ and $34 \%$ of its original fresh weight and water, respectively. There was a disproportionate amount of water loss relative to TDM loss from the lower mature flower fraction during postharvest evaluation, whereas water and TDM losses from the upper mature flower fraction were somewhat more proportional to each other (Fig. 4B, C). The water content (fresh weight basis) of lower mature flowers decreased from $89.5 \pm 0.1 \%$ to $58.3 \pm$ $5.1 \%$ during postharvest evaluation, whereas the water content of the remaining inflorescence fractions ranged between $86 \%$ and $90 \%$ and did not change appreciably during the vase life.

Lower mature flowers lost 26\% more TDM than upper mature flowers during postharvest evaluation (Fig. 4C; 0.24 versus $0.19 \mathrm{~g}$ per eight racemes, respectively). There were numeric TDM declines from the lower rachis and peduncle, but these changes were not statistically significant (Fig. 4C). The expanding apex was the only inflorescence fraction with significant net gains in fresh weight, water, and TDM $(82 \%$, $85 \%$, and $55 \%$ increases, respectively; Fig. $4 \mathrm{~A}-\mathrm{C}$ ). Only $11 \%$ of total raceme fresh weight, water, and TDM was present in the apex at harvest, increasing to between $19 \%$ and $25 \%$ after postharvest evaluation. By contrast, $24 \%$ to $25 \%$ of total raceme fresh weight and water were present in the lower mature flowers at harvest, but only $3 \%$ to $5 \%$ of total raceme fresh weight and water were present in the lower mature flowers at day 6 . Also, $20 \%$ of total raceme TDM was present in lower mature flowers at harvest as compared with $15 \%$ at day 6 . Upper mature flowers experienced smaller declines in water, fresh weight, and TDM than did the lower mature flowers. A preliminary experiment showed that the fresh and dry weight losses from the mature flowers occurred only in the petals and not the pedicel, calyx, gynoecium, or androecium (data not shown). 
Table 1. Probability values resulting from F-tests in repeated measures analysis of variance during 6-d postharvest evaluation of Lupinus havardii 'Texas Sapphire' cut racemes. ${ }^{\mathrm{T}}$

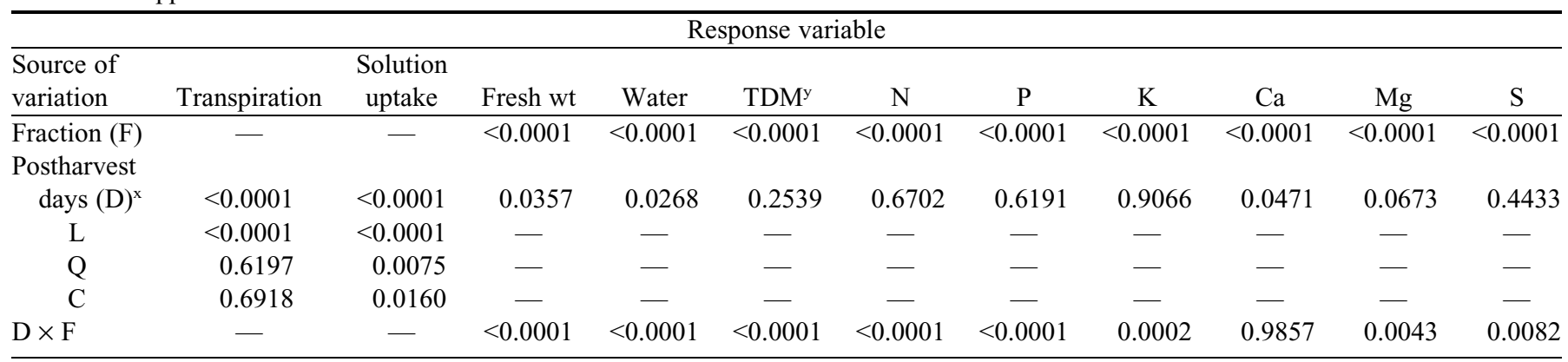

${ }^{\mathrm{z}}$ The response variables were based on eight-raceme experimental units.

yTotal dry matter.

${ }^{x}$ Postharvest days main effect on transpiration and solution uptake partitioned into single degree-of-freedom polynomial contrasts for linear (L), quadratic (Q), and cubic (C) effects.

RACEME Mineral CONTENT. The fraction factor and the fraction $\times$ postharvest day interaction affected raceme $\mathrm{N}, \mathrm{P}$, $\mathrm{K}, \mathrm{Mg}$, and S content (Table 1). During vase life, amounts of $\mathrm{N}, \mathrm{P}, \mathrm{K}, \mathrm{Mg}$, and $\mathrm{S}$ in the apex approximately doubled (Fig. 5). Concurrently, the amounts of N, P, and $\mathrm{K}$ in the lower mature flowers decreased by a similar amount. In relative terms, there was a higher apparent exchange of $\mathrm{N}, \mathrm{P}$, and $\mathrm{K}$ between lower mature flowers and apex than there was for the apparent exchange of TDM noted previously. Net losses of Mg and S from the lower mature flowers were less than the apical $\mathrm{Mg}$ and S gains (Fig. 5).

As observed for fresh weight, water, and TDM, the accumulation of $\mathrm{N}, \mathrm{P}, \mathrm{K}, \mathrm{Mg}$, and $\mathrm{S}$ by the expanding apex occurred at the expense of the mature flowers. Once again, this relationship is graphically illustrated (Fig. 5) by the inverse changes in $\mathrm{N}, \mathrm{P}, \mathrm{K}, \mathrm{Mg}$, and $\mathrm{S}$ content in apex versus mature flowers, particularly lower mature flowers, leading to the postharvest day $\times$ fraction interaction. After $6 \mathrm{~d}$ in the laboratory, the apex contained an average of $18 \%$ more of the total raceme N, $12 \%$ more of the total raceme $\mathrm{P}$, and $6 \%$ to $9 \%$ more of the total raceme $\mathrm{K}, \mathrm{Mg}$, and $\mathrm{S}$ than it did at the time of harvest. By contrast, distributions of these elements changed inversely in

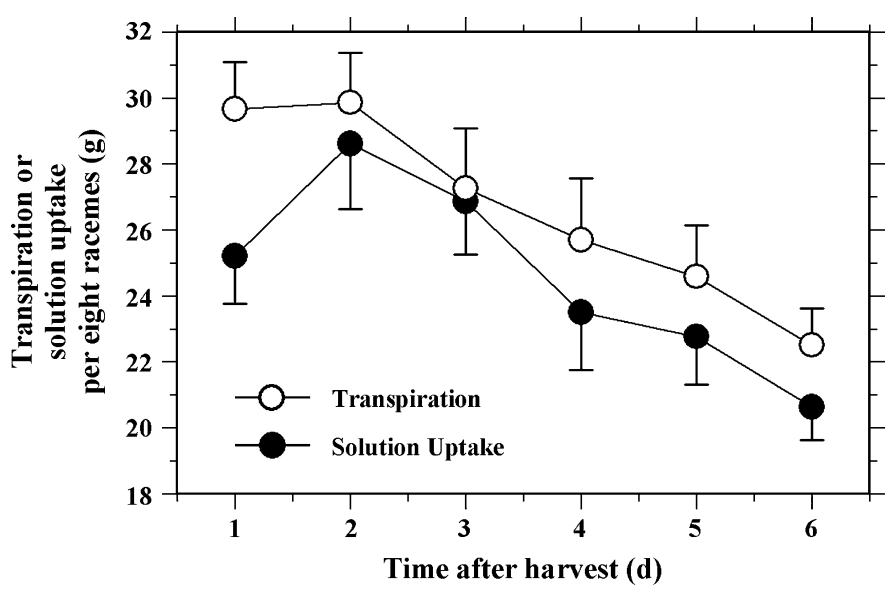

Fig. 3. Daily transpiration and solution uptake of cut Lupinus havardii 'Texas Sapphire' racemes during $6 \mathrm{~d}$ of postharvest evaluation. Each value is the mean $\pm \mathrm{SE}$ of four replications. the mature flowers, especially in the lower mature flower fraction. Both lower and upper mature flowers lost N, but only lower mature flowers lost $\mathrm{P}, \mathrm{K}, \mathrm{Mg}$, and $\mathrm{S}$. In addition to the apical $\mathrm{N}$ sink, the upper rachis represented a second, albeit smaller, $\mathrm{N}$ accumulation site during vase life. Also, the submerged peduncle accumulated a measurable amount of $\mathrm{Mg}$.

There were both fraction and postharvest day main effects on raceme $\mathrm{Ca}$ content (Table 1). For eight racemes, Ca content averaged 3.7 to $4.0 \mathrm{mg}$ in lower and upper mature flowers, $3.8 \mathrm{mg}$ in the peduncle, $2.9 \mathrm{mg}$ in the lower rachis, $2.1 \mathrm{mg}$ in the apex, and $1.5 \mathrm{mg}$ in the upper rachis (Fig. 5). Unlike N, P, K, $\mathrm{Mg}$, and $\mathrm{S}$, the apex did not accumulate a significant amount of $\mathrm{Ca}$ and there were no net $\mathrm{Ca}$ losses from mature flowers (Fig. 5) as indicated by the absence of postharvest day $\times$ fraction interaction on raceme $\mathrm{Ca}$ content (Table 1). In all fractions, however, the $\mathrm{Ca}$ content was numerically higher on day 6 than it was on day 0 (Fig. 5), which led to the main effect of postharvest day on the average Ca content per fraction (Table 1). Average Ca content pooled across the fractions of the eightraceme experimental unit was $2.8 \mathrm{mg}$ on day 0 and $3.2 \mathrm{mg}$ on day 6 . The postharvest day main effect on $\mathrm{Mg}$ content almost reached statistical significance (Table 1). Thus, total $\mathrm{Ca}$ and $\mathrm{Mg}$ contents per eight racemes increased by $15 \%$ to $17 \%$ during postharvest evaluation (Fig. 5).

INTERORGAN SUPPLY AND DEMAND BALANCES. Having established the inverse postharvest changes in water, TDM, N, P, K, $\mathrm{Mg}$, and $\mathrm{S}$ between the generative apex and mature inflorescence tissues, we calculated internal supply and demand balances with data from Figures $4 \mathrm{~B}, 4 \mathrm{C}$, and 5. The results (Tables 2 and 3) omit $\mathrm{Ca}$ because of absence of concurrent $\mathrm{Ca}$ gains and losses among the fractions. Because the apex was the main sink for water, TDM, N, P, K, Mg, and S, we discounted the water and $\mathrm{Mg}$ gains by the submerged peduncle (Figs. 4B and 5) and considered all inflorescence fractions above the peduncle in the water and $\mathrm{Mg}$ balances.

The raceme water deficit was localized to the upper and lower mature flowers. After accounting for the raceme desiccation losses, all of the net apical gain in water $(102 \%)$ could have been supplied by the water deficit attributable to the estimated net water redistribution out of the mature flowers (Table 2). After accounting for total raceme respiratory losses (as inferred by total raceme TDM loss) and if all the TDM redistribution loss from mature flowers was routed to the apex, the net TDM 

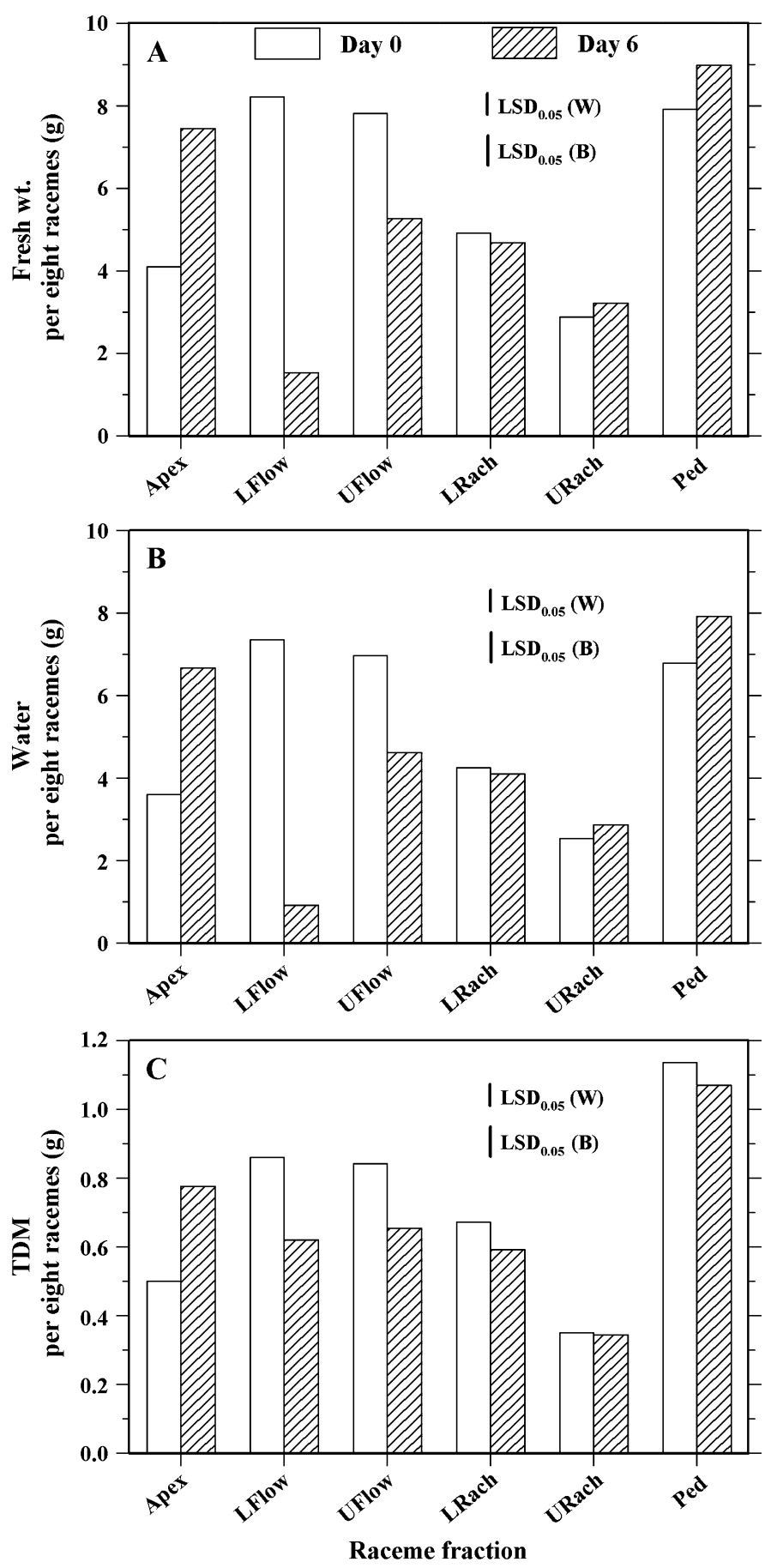

Fig. 4. (A) Fresh weight, (B) weight of water, and (C) weight of total dry matter (TDM) of cut Lupinus havardii 'Texas Sapphire' raceme fractions at harvest (day 0) and after postharvest evaluation (day 6). Raceme fractions are described in Figure 1 with abbreviations as follows: LFlow $=$ lower mature flowers plus pedicels; UFlow = upper mature flowers plus pedicels; LRach = lower rachis subtending lower mature flowers; URach = upper rachis subtending upper mature flowers; and Ped = peduncle. The least significant difference $_{0.05}$ values shown are for mean comparisons within postharvest days (W) and between postharvest days (B). Each value is the mean of four replications. The total weights per eight racemes (all fractions combined) on day 0 and day 6 , respectively, were as follows: fresh weight, $35.8 \pm 1.5$ and $31.1 \pm 0.9 \mathrm{~g}$; water, $31.5 \pm 1.3$ and $27.1 \pm 0.8 \mathrm{~g}$; and TDM, $4.4 \pm 0.2$ and $4.0 \pm$ $0.2 \mathrm{~g}$. export would have supplied an average of $46 \%$ of the apical demand for TDM (Table 2). An average equivalent of $23 \%$ of the water originally present in the lower and upper mature flowers and an average equivalent of $7 \%$ of the TDM originally present in the upper and lower mature flowers were subject to net export (Table 2). From the Table 2 estimates, raceme desiccation and respiratory losses exceeded the water and TDM redistribution losses by $\approx 1.7$ times and $\approx 2.6$ times, respectively.

Net $\mathrm{N}$ export from lower and upper mature flowers could have been allocated to both the apex and upper rachis, although apical $\mathrm{N}$ accumulation exceeded upper rachis $\mathrm{N}$ accumulation by $\approx 6$ times (Fig. 5). Gain in $\mathrm{N}$ by the upper rachis was equivalent to $15 \%$ of the $\mathrm{N}$ loss from the mature flowers, whereas gain in apical $\mathrm{N}$ was equivalent to $84 \%$ of $\mathrm{N}$ loss from mature flowers (Table 3). Thus, quantitatively, the apex appeared to be a more important destination of exported $\mathrm{N}$ from the mature flowers than was the upper rachis fraction. The combined $\mathrm{N}$ losses from lower and upper mature flowers (25.7 mg per eight racemes) could have met all of the apical $\mathrm{N}$ demand while providing for the relatively small accumulation of $\mathrm{N}$ by the upper rachis. That is, the total $\mathrm{N}$ losses from mature flowers accounted for $101 \%$ of the total $\mathrm{N}$ gains by $\mathrm{N}$-importing tissues of the inflorescence (Table 3).

Within the limits of the SE and if all the net losses in $\mathrm{P}$ and $\mathrm{K}$ from the lower mature flowers were destined for the apex, they would have supplied all of the apical P and K demand (Table 3). Slightly over half of the apical Mg and S accumulation was accounted for by net $\mathrm{Mg}$ and $\mathrm{S}$ losses from the lower mature flower fraction (Table 3). An average of $46 \%$ of the apical $\mathrm{Mg}$ and $\mathrm{S}$ demands were apparently supplied from outside the inflorescence.

In lower mature flowers, the efficiency of withdrawal (remobilization) of $\mathrm{N}$ and $\mathrm{P}$ during vase life (remobilization efficiency percent values in Table 3 ) averaged between $53 \%$ and $55 \%$. Also in the lower flowers, the remobilization efficiency values for $\mathrm{K}$ and $\mathrm{S}$ averaged between $31 \%$ and $39 \%$, and for $\mathrm{Mg}$, $14 \%$. In the less developmentally advanced upper mature flowers, $\mathrm{N}$ remobilization efficiency was $32 \%$ less than in the more developmentally advanced lower mature flowers.

\section{Discussion}

This study advances a principle of coordination between sinks and sources in the regulation of internal resource distribution within a cut inflorescence. Attraction of resources by newly opening flowers appears functionally and quantitatively linked to the postharvest reallocation of invested resources from mature flowers. The retranslocation processes may not only play an important role in petal desiccation, but they also draw attention to the developmentally plastic nature of a flower.

The $13 \%$ postharvest loss in total raceme fresh weight is similar to the fresh weight declination observed in a previous study on 'Texas Sapphire' (Picchioni et al., 2002). Inflorescence water deficit was highly localized in mature flowers and temporally associated with a shortfall in solution uptake relative to transpiration, particularly during the first day of postharvest evaluation. These characteristics are indicative of deficit water relations in cut flowers (Borochov and Woodson, 1989; Halevy and Mayak, 1979, 1981; Mayak, 1987; van Doorn, 1997).

Water deficit through desiccation is a central factor associated with cut flower senescence (see previous reviews in this 


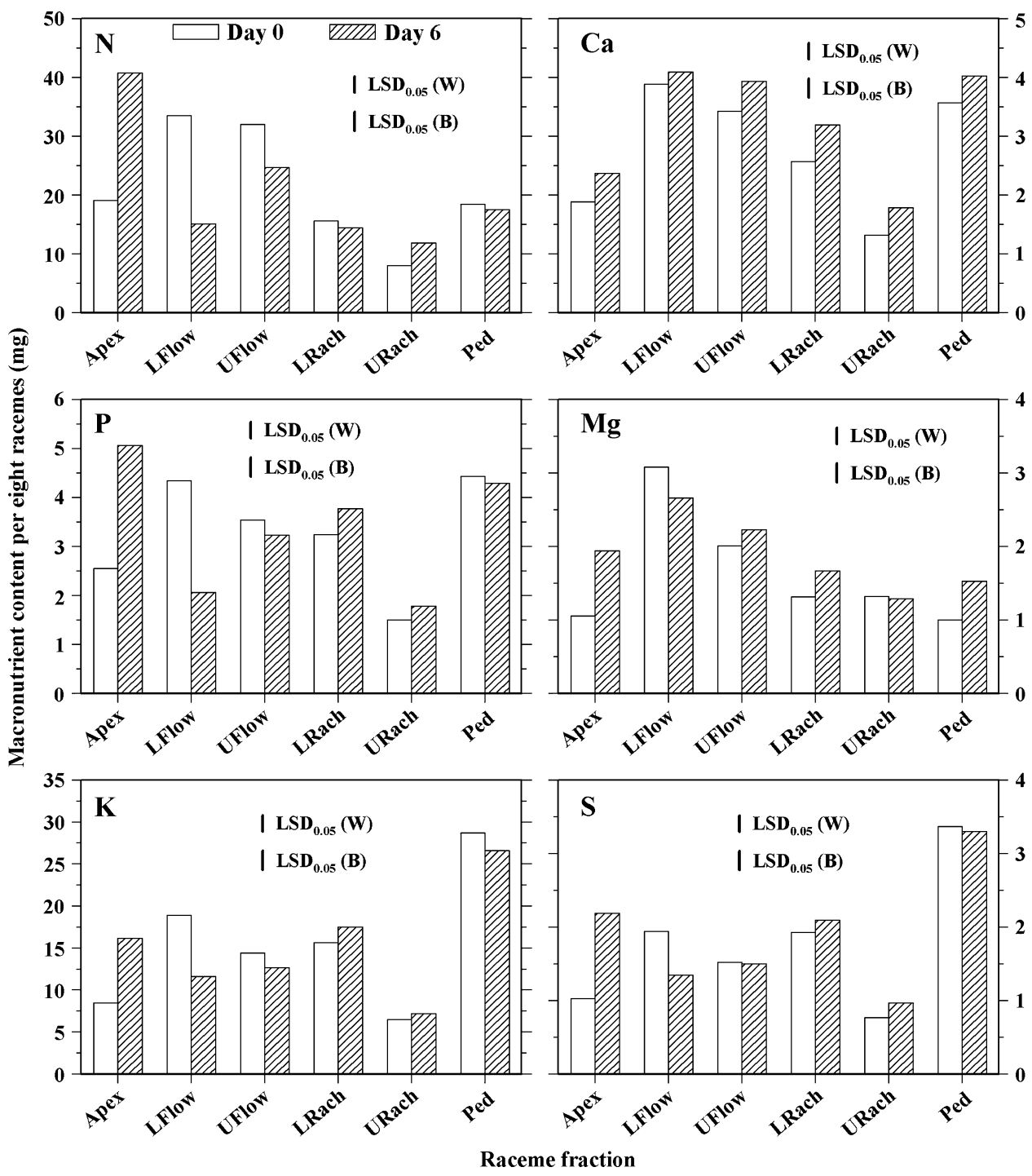

Fig. 5. Macronutrient content of cut Lupinus havardii 'Texas Sapphire' raceme fractions at harvest (day 0) and after postharvest evaluation (day 6). Raceme fractions are described in Figure 1 with abbreviations in Figure 4. The least significant difference ${ }_{0.05}$ values shown are for mean comparisons within postharvest days (W) and between postharvest days (B). Each value is the mean of four replications. The total mineral weights per eight racemes (all fractions combined) on day 0 and day 6 , respectively, were as follows: $\mathrm{N}, 126.7 \pm 3.9$ and $124.2 \pm$ $3.9 \mathrm{mg} ; \mathrm{P}, 19.6 \pm 0.6$ and $20.2 \pm 1.0 \mathrm{mg} ; \mathrm{K}, 92.6 \pm 1.8$ and $91.6 \pm 7.4 \mathrm{mg} ; \mathrm{Ca}, 16.6 \pm 0.8$ and $19.4 \pm 0.8 \mathrm{mg} ; \mathrm{Mg}$, $9.8 \pm 0.4$ and $11.3 \pm 0.5 \mathrm{mg}$; and $\mathrm{S}, 10.5 \pm 0.3$ and $11.4 \pm 0.9 \mathrm{mg}$.

article). However, little emphasis is given to the role of retranslocation processes in water "loss" from petals in support of water and metabolic demands of expanding meristems and opening flowers. In the present study, for example, the localized desiccation in mature flowers ( $8.8 \mathrm{~g}$ water per eight racemes) exceeded the total net loss of water from the raceme above the peduncle by $59 \%$ (Table 2 ). From senescing daylily petals, it has been estimated that up to $50 \%$ of the water loss may enter the phloem stream rather than evaporate (Bieleski, 1995). Our findings on $L$. havardii indicate that the net apical water gain represented $35 \%$ of total net water loss from the lower and upper mature flowers, which were the only exporting fractions of the inflorescence. Therefore, water demands for retranslocation processes may contribute to wilting of petals, which is consistent with a resource "salvaging" role of dying corolla.
Only $46 \%$ of the total apical TDM gain could be accounted for by net losses from mature flowers (Table 2). During vase life, there were numeric reductions in TDM content of lower rachis and peduncle (combined losses of $0.15 \mathrm{~g}$ per eight racemes), but the cvs of those losses exceeded $100 \%$ (data not shown). If the net TDM changes of four replications from lower rachis and peduncle were included in the TDM balance of Table 2, then 96.2 $\pm 6.2 \%$ of apical TDM gain would be accounted for. These findings indicate that a larger number of replications is needed for asserting

2 the locations of all TDM sources within cut 'Texas Sapphire' racemes.

In the upper and lower mature flowers, the declines in TDM content between days 0 and 6 , expressed as percentages of TDM at day 0 , were $22 \%$ and $28 \%$, respectively. These losses are similar to those from senescing petals of uncut petunia, uncut hibiscus (Hibiscus rosasinensis L.), and cut gladiolus 2 (Verlinden, 2003; our calculations from Reid et al., 2002, and Waithaka et al., 2001). Verlinden (2003) concluded that most of the senescencerelated decline in petunia petal dry matter (uncut flowers) was attributable to respiratory loss and not to redistribution loss. The latter conclusion may apply to $L$. havardii (Table 2), but only if we ignore the possible TDM losses from lower rachis and peduncle fractions noted previously. Nonetheless, the apparent TDM redistribution from mature flowers represented only $7 \%$ of the TDM present at the time of harvest. This indicates that apparent TDM redistribution was far less efficient than the redistribution of $\mathrm{N}, \mathrm{P}, \mathrm{K}$, and $\mathrm{S}$.

The inflorescence we studied was severely resource-limited in that it was detached, leafless, growing, and standing in deionized water for almost 1 week. After $6 \mathrm{~d}$, newly opened flowers at the apex effectively increased the total number of open flowers counted at harvest (day 0 ) by over $40 \%$. It should not be surprising that when the onset of apical expansion set up demands for $\mathrm{N}, \mathrm{P}$, and $\mathrm{K}$, the demands were met entirely from within the inflorescence, although lack of similar data in the floriculture literature is somewhat surprising. Asparagine and glutamine contain $\approx 20 \% \mathrm{~N}$ and are the two major forms of $\mathrm{N}$ in the phloem fluids of Lupinus albus $\mathrm{L}$. and L. angustifolius $\mathrm{L}$. (Pate et al., 1998). When expressed on the basis of amino-N (not measured in the present study), the postharvest apical elemental $\mathrm{N}$ gain (21.6 mg N per eight racemes in Table 3) 
Table 2. Balances for the amounts of water and total dry matter (TDM) between Lupinus havardii 'Texas Sapphire' cut raceme apex and upper and lower mature flowers during 6-d postharvest evaluation..$^{z, y}$

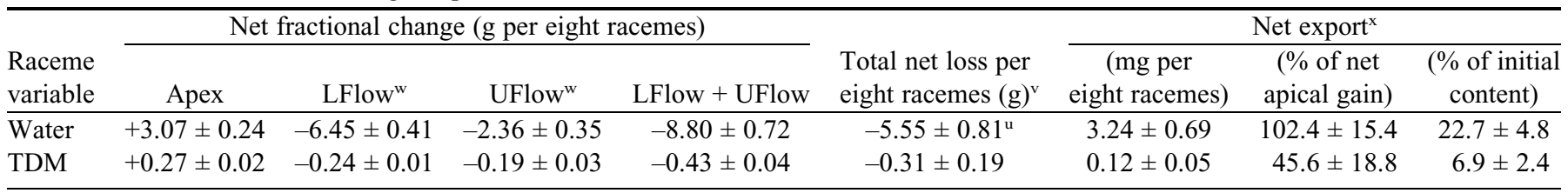

${ }^{\mathrm{z} I n d i v i d u a l ~ n e t ~ f r a c t i o n a l ~ l o s s e s ~ w i t h i n ~ e i g h t ~ r a c e m e s ~ w e r e ~ a t t r i b u t a b l e ~ t o ~ b o t h ~ l o s s ~ t o ~ a t m o s p h e r e ~ a n d ~ r e d i s t r i b u t i o n, ~ a n d ~ t h e ~ t o t a l ~ n e t ~ l o s s e s ~ p e r ~}$ eight racemes (all fractions weighed together) reflected losses to atmosphere. Positive net changes indicate net gains; negative net changes are net losses. Data obtained from Figure 4B, C, including only the fractions that expressed significant net change during evaluation (by least significant difference 0.05 between days).

${ }^{\mathrm{y}}$ Each value is the mean $\pm \mathrm{SE}$ of four, eight-raceme replications.

${ }^{x}$ Estimated by subtracting the total net losses per eight racemes (all fractions weighed together) from the summation of individual net fractional losses. Initial water and TDM content defined as sum in lower and upper mature flowers (grams per eight racemes) at day 0 of postharvest evaluation.

${ }^{\mathrm{w}}$ LFlow $=$ lower mature flowers plus pedicels; UFlow $=$ upper mature flowers plus pedicels

vetermined directly using sum total of all fraction weights taken together at 0 and $6 \mathrm{~d}$ of evaluation with the negative values representing net losses from the entire inflorescence and reflecting desiccation losses (for water) or respiratory losses (for TDM).

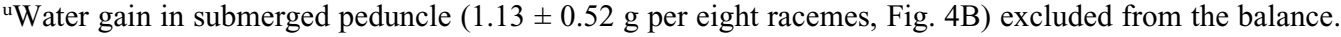

could have accounted for $\approx 40 \%$ of the apical TDM gain shown in Table 2.

Postharvest partitioning of minerals during our study followed patterns that are to be expected of elemental phloem mobilities in vegetative organs (Hill, 1980; Larcher, 1975). The fraction main effect revealed that relatively immobile Ca was more abundant in older inflorescence tissues such as the mature flowers, lower rachis, and peduncle as compared with the younger fractions of expanding flowers at the apex along with the upper rachis. An identical trend was observed for $\mathrm{Ca}$ concentration (data not shown). In contrast to the absence of postharvest day $\times$ fraction interaction on $\mathrm{Ca}$ content, the presence of interaction on the amounts of relatively mobile $\mathrm{N}, \mathrm{P}, \mathrm{K}, \mathrm{Mg}$, and S resulted mainly from concurrent releases from lower mature flowers and gains by the apex.

The postharvest day main effect on average $\mathrm{Ca}$ content per fraction $(P=0.0471)$, and the nearly significant postharvest day main effect on average $\mathrm{Mg}$ content per fraction $(P=0.0673)$, may have resulted from unintentional $\mathrm{Ca}$ and $\mathrm{Mg}$ contamination in the deionized water used for the vase solution. The product of total dissolved solids in the deionized water uptake solution $\left(32 \mathrm{mg} \cdot \mathrm{L}^{-1}\right)$ and the total 6-d solution uptake (147.6 g water per eight racemes) was $4.7 \mathrm{mg}$ total dissolved solutes, which compares favorably with the $4.3 \mathrm{mg}$ per unit eightraceme increase in the content of $\mathrm{Ca}$ plus $\mathrm{Mg}$ between 0 and $6 \mathrm{~d}$ of vase life (see caption of Fig. 5). The marginal $P$ value for F-test on postharvest days main effect supports the likelihood that almost half of the apical Mg accumulation came from the vase solution. Likewise, uptake of sulfate from the deionized water could have accounted for the remainder of apical $\mathrm{S}$ accumulation not supported by lower mature flowers in Table 3, although the postharvest day main effect on average $\mathrm{S}$ content per fraction did not reach statistical significance.

The transition from a sink to a source is one of the most fundamentally important developmental changes in the ontogeny of a leaf (Turgeon, 1989), which in turn is the most widely studied source organ in higher plants (Lalonde et al., 2004; Noodén, 1988; Pate, 1975). In contrast to photosynthetic centers, there is relatively little awareness of sink-to-source transition in flowers. The Bieleski (1995) study was the first to discretely recognize three underappreciated aspects of petal development: 1) that the ability of a senescing petal to undergo a developmentally regulated transition from an unloading (importing) organ to a loading (exporting) organ occurs rapidly, within only hours in his ephemeral daylily case study; 2) that the remarkable persistence and viability of functional petal phloem in the center of an autolytic, "dismantling" environment is essential for the sink-to-source transition; and 3 ) that phloem export rates in senescing petals may rival or exceed those of vegetative organs on an intact plant. Bieleski's paradigm suggests that designation of the flower as a "unidirectional" organ - growth and importing stages followed by senescence-is an oversimplification of flower development. Our findings support Bieleski's model. Mature flowers on $L$. havardii racemes function as a sink only days before harvest but switch to a source at or near the beginning of the postharvest period and therefore are developmentally plastic organs.

The present floricultural data are unique to whole plant data on agronomic Lupinus L. taxa such as L. albus and L. angustifolius (Hocking, 1980; Hocking and Pate, 1977, 1978; Lagunes-Espinoza et al., 2000; Milford et al., 1999). In these and other whole plant studies, reproductive or vegetative sink demand is partially met by concurrent mineral uptake, C and $\mathrm{N}$ assimilation, and xylem-to-phloem transfer in the shoot (Bulman and Smith, 1993; Mattsson et al., 1993; Pate, 1975; Souza et al., 1998). Thus, in the agronomic Lupinus sp. studies mentioned previously, no more than $55 \%$ of the $\mathrm{N}, \mathrm{P}$, and $\mathrm{K}$ supply to the sink was supplied by N, P, and K redistribution from vegetative sources. By contrast, at least $94 \%$ of the sink demands for $\mathrm{N}, \mathrm{P}$, and $\mathrm{K}$ in the present cut flower study were supplied by previous $\mathrm{N}, \mathrm{P}$, and $\mathrm{K}$ investments in reproductive tissues of the inflorescence.

Despite the major distinction in nutrient sources between the agronomic Lupinus sp. studies and the present Lupinus sp. study, the cut flower model shares an important similarity with whole plant senescence. In both whole plants and cut flowers, there is a changing balance of demand set up by competitive meristematic centers that is coupled with degeneration of mature organs supplying the demand centers. We are unaware of any similar studies reporting internal supply and demand balances of indeterminate inflorescences like in the present investigation; thus, whether other cut flowers behave in a similar manner remains to be determined. 


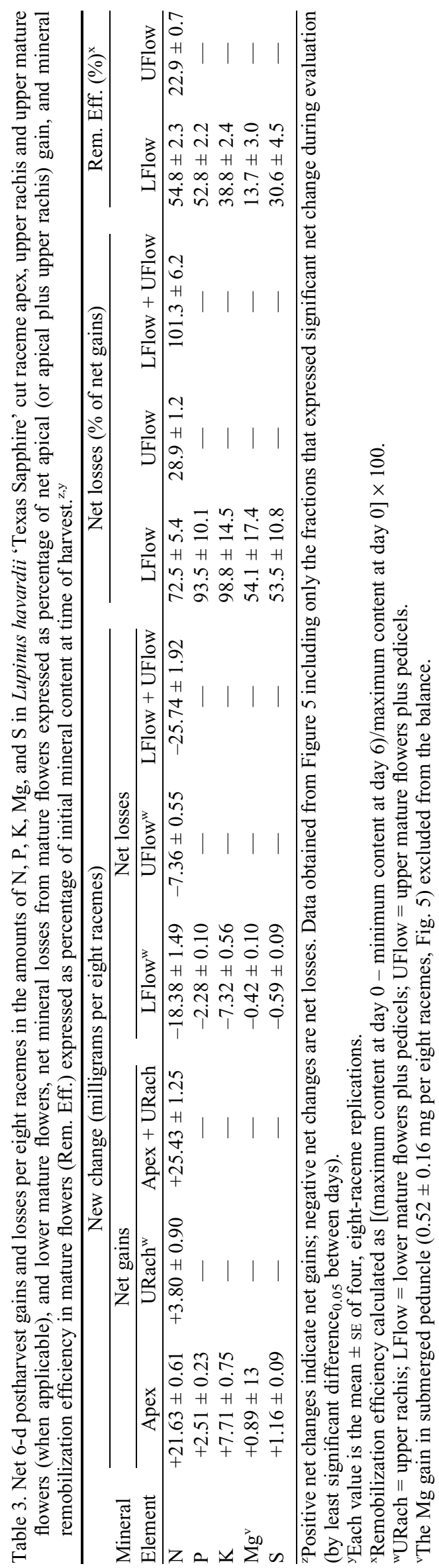

\section{Literature Cited}

Bieleski, R.L. 1995. Onset of phloem export from senescent petals of daylily. Plant Physiol. 109:557-565.

Borochov, A. and W.R. Woodson. 1989. Physiology and biochemistry of flower petal senescence. Hort. Rev. (Amer. Soc. Hort. Sci.) 11: $15-43$.

Bulman, P. and D.L. Smith. 1993. Accumulation and redistribution of dry matter and nitrogen by spring barley. Agron. J. 85:1114-1121.

Davis, T.D., S.W. George, W.A. Mackay, and J.M. Parsons. 1994. Development of Texas bluebonnets into floricultural crops. HortScience 29:1110-1211.

Davis, T.D., W.A. Mackay, and N. Sankhla. 1995. Postharvest characteristics of cut inflorescences of Lupinus havardii. HortTechnology 5:247-249.

Dracup, M. and E.J.M. Kirby. 1996. Lupin development guide. University of Western Australia Press, Nedlands, Western Australia.

Gavlak, R.G., D.A. Horneck, and R.O. Miller. 1994. Plant, soil, and water reference methods for the western region. Western Coordinating Committee, Western Reg. Ext. Publ. 125. Western Rural Dev. Ctr., Corvallis, Ore.

Halevy, A.H. and S. Mayak. 1979. Senescence and postharvest physiology of cut flowers, Part 1. Hort. Rev. (Amer. Soc. Hort. Sci.) 1:204-236.

Halevy, A.H. and S. Mayak. 1981. Senescence and postharvest physiology of cut flowers-Part 2. Hort. Rev. (Amer. Soc. Hort. Sci.) 3:59-143.

Hill, J. 1980. The remobilization of nutrients from leaves. J. Plant Nutr. 2:407-444.

Hocking, P.J. 1980. Redistribution of nutrient elements from cotyledons of two species of annual legumes during germination and seedling growth. Ann. Bot. (Lond.) 45:383-396.

Hocking, P.J. and J.S. Pate. 1977. Mobilization of minerals to developing seeds of legumes. Ann. Bot. (Lond.) 41:1259-1278.

Hocking, P.J. and J.S. Pate. 1978. Accumulation and distribution of mineral elements in the annual lupins Lupinus albus L. and Lupinus angustifolius L. Austral. J. Agr. Res. 29:267-280.

Jones, Jr., J.B., B. Wolf, and H.A. Mills. 1991. Plant analysis handbook: A practical sampling, preparation, analysis, and interpretation guide. Micro-Macro, Athens, Ga.

Lagunes-Espinoza, L.C., C. Huyghe, J. Papineau, and I. Shield. 2000. Dry matter and nitrogen accumulation during pod wall development of white lupin genotypes differing in proportion of pod walls. J. Agr. Sci. 135:389-397.

Lalonde, S., D. Wipf, and W.B. Frommer. 2004. Transport mechanisms for organic forms of carbon and nitrogen between source and sink. Annu. Rev. Plant Biol. 55:341-372.

Larcher, W. 1975. Physiological plant ecology. Springer-Verlag, N.Y. Mackay, W.A. and T.D. Davis. 1998. 'Texas Sapphire' and 'Texas Ice' long-stem bluebonnets (Lupinus havardii). HortScience 33:348-349.

Mattsson, M., T. Lundborg, and C.M. Larsson. 1993. Nitrogen utilization in N-limited barley during vegetative and generative growth. IV. Translocation and remobilization of nitrogen. J. Expt. Bot. 44:537-546.

Mayak, S. 1987. Senescence of cut flowers. HortScience 22:863-865. Milford, G.F.J., I.F. Shield, H.J. Stevenson, T. Scott, and J.E. Leach. 1999. Seed and pod development of autumn-sown, determinate white lupins (Lupinus albus) in relation to the assimilation and distribution of dry matter and nitrogen in crops grown at different densities. J. Agr. Sci. 133:141-150.

Nichols, R. and L.C. Ho. 1975a. Effects of ethylene and sucrose on translocation of dry matter and ${ }^{14} \mathrm{C}$-sucrose in the cut flower of the glasshouse carnation (Dianthus caryophyllus) during senescence. Ann. Bot. (Lond.) 39:287-296.

Nichols, R. and L.C. Ho. 1975b. An effect of ethylene on the distribution of ${ }^{14} \mathrm{C}$-sucrose from the petals to other flower parts in the senescent cut inflorescence of Dianthus caryophyllus. Ann. Bot. (Lond.) 39:433-438. 
Noodén, L.D. 1988. Whole plant senescence, p. 391-439. In: L.D. Noodén and A.C. Leopold (eds.). Senescence and aging in plants. Academic Press, N.Y.

Pate, J.S. 1975. Exchange of solutes between phloem and xylem and circulation in the whole plant, p. 451-473. In: M.H. Zimmerman and J.A. Milburn (eds.). Transport in plants. I. Phloem transport. Encyclopedia Plant Physiol. New Ser. Vol. 1. Springer-Verlag, N.Y.

Pate, J.S., R.J.N. Emery, and C.A. Atkins. 1998. Transport physiology and partitioning, p. 181-226. In: J.S. Gladstones, C.A. Atkins, and J. Hamblin (eds.). Lupins as crop plants: Biology, production, and utilization. CAB International, N.Y.

Picchioni, G.A., M. Valenzuela-Vázquez, and L.W. Murray. 2002. Calcium and 1-methylcyclopropene delay desiccation of Lupinus havardii cut racemes. HortScience 37:122-125.

Reid, M.S., B. Wollenweber, and M. Serek. 2002. Carbon balance and ethylene in the postharvest life of flowering hibiscus. Postharvest Biol. Technol. 25:227-233.

Sankhla, N., W.A. Mackay, and T.D. Davis. 2001. Extension of vaselife and prevention of ethylene-induced flower shattering in Lupinus havardii by 1-methylcyclopropene. Acta Hort. 543: 75-78.

Schroeder, K.R. and D.P. Stimart. 2001. Genetic analysis of cut-flower longevity in Antirrhinum majus. J. Amer. Soc. Hort. Sci. 126: 200-204.
Serek, M., R.B. Jones, and M.S. Reid. 1994. Role of ethylene in opening and senescence of Gladiolus sp. flowers. J. Amer. Soc. Hort. Sci. 119:1014-1019.

Souza, S., E. Mariam, L.M. Stark, and M.S. Fernandes. 1998. Nitrogen remobilization during the reproductive period in two Brazilian rice varieties. J. Plant Nutr. 21:2049-2063.

Steel, R.G.D. and J.H. Torrie. 1980. Principles and procedures of statistics: A biometrical approach. 2nd ed. McGraw-Hill, N.Y.

Thomas, H., H.J. Ougham, C. Wagstaff, and A.D. Stead. 2003. Defining senescence and death. J. Expt. Bot. 54:1127-1132.

Thomas, H. and J.L. Stoddart. 1980. Leaf senescence. Annu. Rev. Plant Physiol. 31:83-111.

Turgeon, R. 1989. The sink-source transition in leaves. Annu. Rev. Plant Physiol. Mol. Biol. 40:119-138.

van Doorn, W.G. 1997. Water relations of cut flowers. Hort. Rev. (Amer. Soc. Hort. Sci.) 18:1-85.

Vasquez, K.L. 1998. Ethylene production and sensitivity in Lupinus havardii, big bend bluebonnet, New Mexico State Univ., Las Cruces. MS Thesis.

Verlinden, S. 2003. Changes in mineral nutrient concentrations in petunia corollas during development and senescence. HortScience 38:71-74.

Waithaka, K., L.L. Dodge, and M.S. Reid. 2001. Carbohydrate traffic during opening of gladiolus florets. J. Hort. Sci. Biotechnol. 76:120-124. 